\title{
THE TRANSLOCATION OF CALCIUM IN A SOIL
}

\author{
A THESIS \\ PRESENTED TO THE FACULTY OF THE GRADUATE SCHOOL \\ OF CORNELL UNIVERSITY FOR THE DEGREE OF \\ DOCTOR OF PHILOSOPHY
}

BY

\section{BENJAMIN DUNBAR WILSON}

\author{
FEBRUARY, 1918
}

Reprinted from Memolr 17, December, 1918 of Cornell University Agrfcultural Experiment Station 



\title{
THE TRANSLOCATION OF CALCIUM IN A SOIL
}

\author{
A THESIS \\ PRESENTED TO THE FACULTY OF THE GRADUATE SCHOOL \\ OF CORNELL UNIVERSITY FOR THE DEGREE OF \\ DOCTOR OF PHILOSOPHY
} BY BENJAMIN DUNBAR WILSON

\author{
FEBRUARY, 1918
}





\section{CONTENTS}

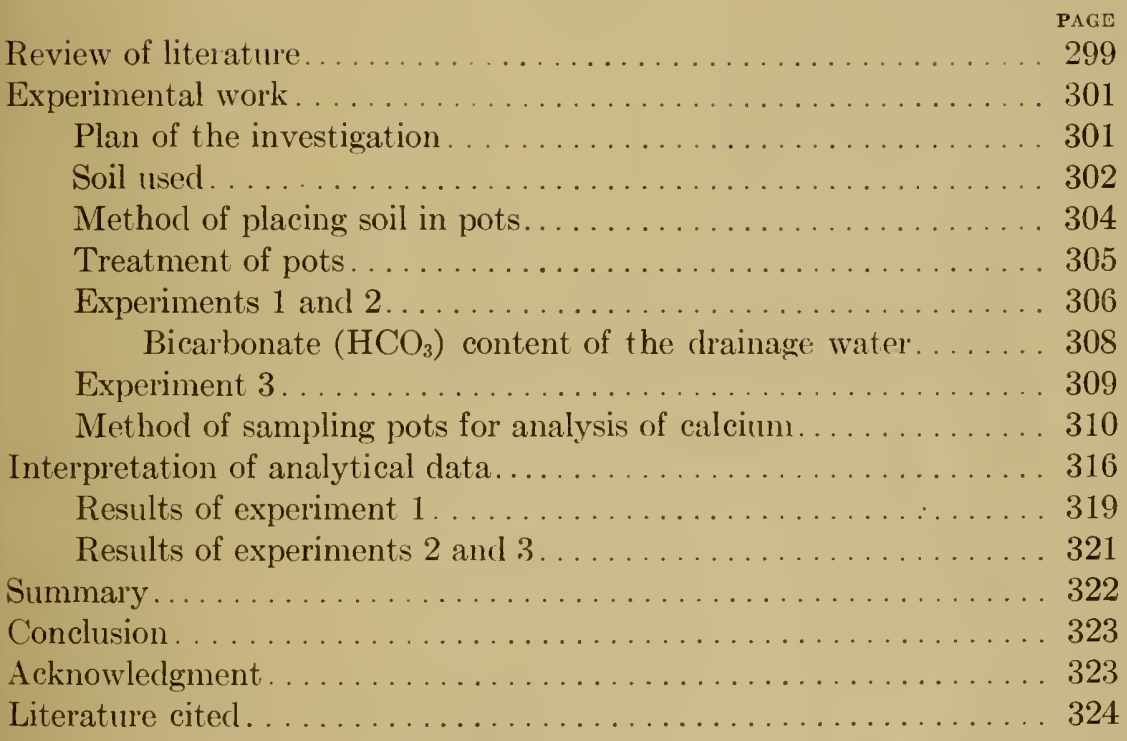







\section{THE TRANSLOCATION OF CALCIUM IN A SOIL}

\section{Benjamin Dunbar Wilson}

The presence of calcium in soil is of extreme importance. The action of this element, when applied in different chemical combinations to soil, has been investigated extensively. In spite of the fact that much has been written on the subject of calcium in soil, it is evident from a review of the literature that the movement of calcium in soil has reccived but little attention. Definite information in relation to the translocation of calcium in soil, under carefully controlled laboratory or field conditions, is unsupplied.

The present investigation was undertaken in an attempt to answer the following questions: (1) Does the calcium applied to a soil move downward or does it remain in the upper few inches of soil? (2) If the calcium does move downward, to what extent does it move?

\section{REVIEW OF LITERATURE}

The only study that has been made on the downward movement of calcium in soils under controlled laboratory conditions, so far as the writer has been able to discover, is that of Broughton (1912). ${ }^{1}$ In that experiment the movement of calcium thru sandy. loam, and clay soils was determined, the calcium being applied in different forms. It was found that the movement of calcium thru a soil was governed largely by the physical constitution of the latter, the calcium salts diffusing most rapidly thru a sandy soil, less rapidly thru a loan soil, and only slightly thru a clay soil. Some of the differences which the author reports in the novement of calcium, resulting from the different treatments that were used, might have disappeared had the treatments been repeated a greater number of times; also, the method employed for sampling pots at different intervals necessitated a disturbance of the soils within the pots, which may have resulted in some mechanical movement of calcium.

Several investigators have endeavored to determine the translocation of calcium in field soils by comparing the quantity of calcium found at

\footnotetext{
1 Dates in parenthesis refer to Literalure cited, page 324.
} 
different depths in soils that had received an application of calcium in some form with that in other soils of the same type that had not been treated with any form of calcium. MeIntire (1913) analyzed a silty loam soil for calcium at different depths from plats that had received large applications of either calcium oxid or calcium carbonate for a period of thirty years. From a comparison of the calcium found in the treated soil with that found in the soil from adjacent untreated plats, it was concluded that calcium applied in either form at the surface of such soil moves downward very slowly, most of it remaining for years in the surface soil.

The analyses for calcium earbonate in the surface soils and subsoils of Broadbalk and Hoos fields at Rothamsted, which have been made at different times since 1865 as reported by Hall and Miller (1905), show that the subsoils have decreased in calcium, as well as the surface soils, which latter had received large applications of calciun previous to 1865 and which since that time have received yearly, for more than fifty years, the same fertilizer treatments. The results indicate that there has been no accumulation of calcium in the subsoils, altho there seems to be a tendency for an increase in the subsoils where ammonium sulfate has been applied from year to year to the surface soils.

Veitch (1904) studied the downward movement of calcium in soils by determining the soil acidity at varied depths. The results of his investigation showed that when calcium oxid was applied to soils its neutralizing effect was exerted only to the depth to which it was incorporated with the soils during the various processes of preparation and cultivation.

Ames and Schollenberger (1916) present data to show the depth of soil affected by applications of calcium salts. Soils that had been so treated were sampled at different depths and their lime requirements determined by the Hopkins and vacuum methods. The indications were that light applications of lime have considerable effect on the subsoil, at least to a depth of twenty-four inches.

White (1914) reports, from studies made on soils in the field, that calcium does not move horizontally to any considerable degree by diffusion, as soil rich in calcium carbonate was found within eighteen inches of soil distinetly acid. 
King (1904) studied the capillary movement of calcium thru soils by filling galvanized cylinders, provided with reservoirs at their bases, with different types of soil. A calcium solution applied at the bottom of the soil columns was permitted to rise by capillarity thru the soils. The results of the experiment tended to show that there was a slight upward movement of calcium.

A comparison of the calcium content of surface and subsurface soils as reported by Smith (1884), Snyder (1899), Ames and Gaither (1913), Shorey, Fry, and Hazen (1917), and others, does not permit of any general conclusion as to whether surface soils or subsurface soils contain the greater amount of calcium. Consequently such a consideration is of no value in a study of the translocation of calcium in soil.

A review of the literature reveals the fact that the studies thus far made on the movement of calcium in soil have been confined almost entirely to field experimentation and have been carried on as side experiments. Results obtained under such conditions are not absolute. The calcium content of soils is not always constant, and in comparing one soil with another this fact alone may lead to erroneous conclusions.

Some investigators have used a method for the determination of lime requirement as a measure of calcium in soils. Such a practice is open to criticism, as a lime requirement is an estimation of the absorptive power of a soil for basic material, not a measure of its calcium content. If calcium should liberate any of the soil bases, such a reaction might account for any decrease found in the lime requirement of the subsoil rather than the actual downward movement of calcium.

As previously stated, very little experimental evidence is available concerning the movement of calciun in soil uncler carefully controlled conditions. In view of this fact the experiments detailed herein were undertaken.

\section{EXPERIMENTAL WORK}

Plan of the investigation

The investigation consisted of three experiments. These are briefly outlined as follows:

Experiment 1.- In the first experiment the translocation of calcium in soil was studied by leaching soil contained in pots with distilled water. The soil was placed in the pots in three layers. In some of the pots 
calcium as oxid, and in others calcrum as earbonate, was incorporated with the surface layer to test the possible downward movement of this element; in other pots the calcium was mixed with the bottom layer of soil to determine its tendency to move upward. The downward movements of calcium oxid and calcium carbonate, when applied to a soil in medium, large, and excessive amounts and in equivalent quantities of calcium, were collated. The oxid was added as burned limestone, and the carbonate as ground limestone and precipitated calcium carbonate. ${ }^{2}$ The state of division of the ground limestone used in the experiment was such that it passed thru a 100-mesh sieve and was held on a 200-mesh sicve. One set of the pots was leached for six months and another set for one year, and at the end of each period the layers of soil in each pot were analyzed for total calcium in contemplation of determining its movement. The experiment was set up in quadruplieate.

Experiment 2.- In the second experiment the downward movement of calcium was detcrmined when lots of ground limestone, differing in fineness of division, were appliert to the soil in equivalent quantities. Pots filled with soil in three layers were treated with the ground limestone in the top layer, and were leached with distilled water for one year. Limestone of four grades of fineness was used in treating the different pots, the treatment with each grade being repeated four times.

Experiment 3.- In the third experiment a comparative study was made of the diffusibility of calcium in a cropped and an uncropped soil. Pots were filled with soil arranged in layers, treated in the surface layer with burned limestone, and leached with distilled water for five months.

\section{Soil used}

The soil used in the investigation was a Dunkirk clayey silt loam, a glacial till soil low in organic matter. It comprises the greater part of the soil on the farm of the Cornell University Agrieultural Experiment Station, and for this reason it was selected for study. A chemical and a mechanical analysis of this soil, taken from the files of the Department of Soil Technology, Cornell University, follow:

2 Twice as much ground limestone as burned limestone was applied to the pots. Consequently the quantity of calcium arlded to the pots treated with ground limestone was slightly in excess of that added to the pots that received a treatment of burned limestone. As it is customary when applying calcium to fielil soils to follow such a procedure, this ratio was used in experiments 1 and 2. 
Chemical' Analysis (Bulk)

(An average of the analyses of nine samples)

Surface per cent

Organic carbon.

1.670

Carbon dioxid.

Trace

Potassium oxid

1.740

Calcium oxid.

0.430

Magnesium oxid

0.450

Sodium oxid

1.090

Nitrogen

0.186

Phosphoric anhydrid

0.123

\section{Mechanical Analysis}

(An average of the analyses of three samples)

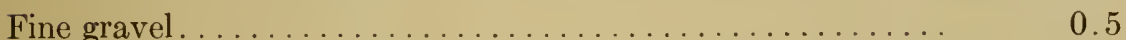

Coarse sand.............................. 0.8

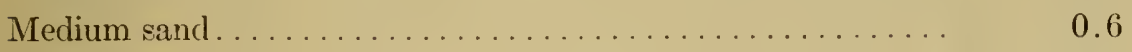

Fine sand............................... $\quad 2.7$

Very fine sand . . . . . . . . . . . . . . . . . . . . . . . . .

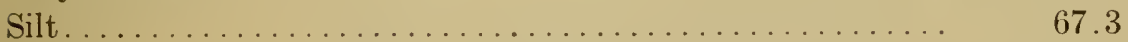

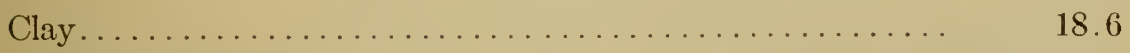

Total. . . . . . . . . . . . . . . . . . . . . . . . . 100.0

A large quantity of soil was necessary to carry out the experiments, and this was collected at three different times. For convenience, the three soils thus obtained are designated as $\mathrm{X}, \mathrm{Y}$, and $\mathrm{Z}$. Soil $\mathrm{X}$ was used for experiment 1 , soil $\mathrm{Y}$ for experiment 2 , and soil $\mathrm{Z}$ for experiment 3. All three soils were surface soils taken from a roadside adjoining Caldwell Field, a part of the experiment station farm. Each lot was taken to the greenhouse, where it was screened and thoroly mixed, the screenings being discarded. The three soils were in good physical condition.

A representative sample was taken from each of the soils and prepared for analysis. The lime requirement and the calcium content of each are 
shown in table 1. The lime requirements were determined by the Veitch (1904) method, and are expressed as parts per million of calcium oxid necessary to correct the acidity in the oven-dried soils. Calcium was determined as recommended by the Ohio Agricultural Experiment Station (Ames and Gaither, 1913). This method was used for all the determinations of calcium that were made thruout the investigation, and consists essentially in fusing the soil with a mixture of sodium and potassium carbonates, precipitating the calcium as calcium oxalate after the removal of silicon, iron, aluminum, and manganese, and titrating the filtered precipitate with a standard solution of potassium permanganate.

Table 1. Lime Requirements and Percentages of Calcium in Solls $\mathrm{X}, \mathrm{Y}$, and $\mathrm{Z}$

\begin{tabular}{|c|c|c|}
\hline Soil & $\begin{array}{c}\text { Lime require- } \\
\text { ment of dry soil } \\
\text { (parts per } \\
\text { million } \mathrm{CaO} \text { ) }\end{array}$ & $\begin{array}{l}\text { Percentage } \\
\text { of total } \\
\text { calcium }\end{array}$ \\
\hline 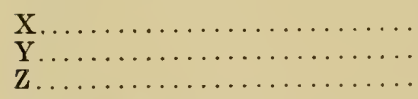 & $\begin{array}{r}900 \\
800 \\
1,300\end{array}$ & $\begin{array}{l}0.328 \\
0.300 \\
0.220\end{array}$ \\
\hline
\end{tabular}

Method of placing soil in pots

Glazed earthen pots 10 inches in height and $9 \frac{1}{2}$ inches in inside diameter were used for the experiments. In each pot was placed thirteen kilograms of soil to form three layers. Of the eighty pots used, seventy-two were filled in the following manner: Into the bottom of each pot was packed five kilograms of soil, which formed the bottom, or third, layer. Over the surface of this layer a piece of wire netting was placed, and on top of it another five-kilogram portion of soil was packed, which constituted the middle, or second, layer. The remaining three kilograms of soil made up the top, or first, layer, which was separated from the middle, or second, layer by a second piece of wire netting. The calcium oxid or calcium carbonate with which the pots were treated was incorporated with the soil making up the first layer before this was placed in the pots.

The remaining eight pots were filled with soil so placed that the upward movement of calcium could be studied. In order to observe this move- 
ment, the three-kilogram portions of soil containing the calcium treatments were placed in the bottom of the pots, the top and middle layers consisting of five kilograms each. The layers were separated with wire netting, as described above.

The soil was placed in the pots in layers in order that the calciumtreated soil might be separated from the untreated soil, as well as for a division of the latter, when the pots were opened. The object in dividing the untreated soil into layers was to make possible a comparison of the amounts of calcium in them with reference to their distance from the calcium-treated soil.

\section{Treatment of pots}

The treatment of the pots in the three experiments may be outlined as follows:

Experiment 1. Translocation of Calcium Oxid and Calcium Carbonate in Soil

\begin{tabular}{|c|c|c|}
\hline Nos. of pots & $\begin{array}{c}\text { Treatment } \\
\text { (pounds per acre) }\end{array}$ & $\begin{array}{c}\text { Treated } \\
\text { layer }\end{array}$ \\
\hline $\begin{array}{l}1,2,3,4 \ldots \\
5,6,7,8 \ldots\end{array}$ & $\begin{array}{l}3,000 \mathrm{CaO} \ldots \ldots \\
3,000 \mathrm{CaO} \ldots\end{array}$ & $\begin{array}{l}\text { Top } \\
\text { Top }\end{array}$ \\
\hline $\begin{array}{l}9,10,11,12 \ldots \ldots \ldots \\
13,14,15,16 \ldots \ldots \ldots\end{array}$ & $\begin{array}{l}9,000 \mathrm{CaO} \ldots \ldots \\
9,000 \mathrm{CaO} \ldots \ldots\end{array}$ & $\begin{array}{l}\text { Top } \\
\text { Top }\end{array}$ \\
\hline $\begin{array}{l}17,18,19,20 \ldots \\
21,22,23,24 \ldots\end{array}$ & $\begin{array}{l}15,000 \mathrm{CaO} \ldots \ldots \\
15,000 \mathrm{CaO} \ldots \ldots\end{array}$ & $\begin{array}{l}\text { Top } \\
\text { Top }\end{array}$ \\
\hline $25,26,27,28$. & $15,000 \mathrm{CaO} \ldots$ & Bottom \\
\hline $\begin{array}{l}29,30,31,32 \ldots \\
33,34,35,36 \ldots\end{array}$ & $\begin{array}{l}6,000 \mathrm{CaCO}_{3} \ldots \ldots \\
6,000 \mathrm{CaCO}_{3} \ldots \ldots\end{array}$ & $\begin{array}{l}\text { Top } \\
\text { Top }\end{array}$ \\
\hline $\begin{array}{l}37,38,39,40 \ldots \ldots \\
41,42,43,44 \ldots \ldots\end{array}$ & $\begin{array}{l}18,000 \mathrm{CaCO}_{3} \ldots \\
18,000 \mathrm{CaCO}_{3} \ldots\end{array}$ & $\begin{array}{l}\text { Top } \\
\text { Top }\end{array}$ \\
\hline $\begin{array}{l}45,46,47,48 \ldots \\
49,50,51,52 \ldots\end{array}$ & $\begin{array}{l}30,000 \mathrm{CaCO}_{3} \ldots \\
30,000 \mathrm{CaCO}_{3} \ldots\end{array}$ & $\begin{array}{l}\text { Top } \\
\text { Top }\end{array}$ \\
\hline $53,54,55,56 \ldots$ & $30,000 \mathrm{CaCO}_{3} \ldots \ldots$ & Bottom \\
\hline
\end{tabular}


Experiment 2. Downward Movement of Ground Limestone of Different Degrees of Fineness thru SoIL

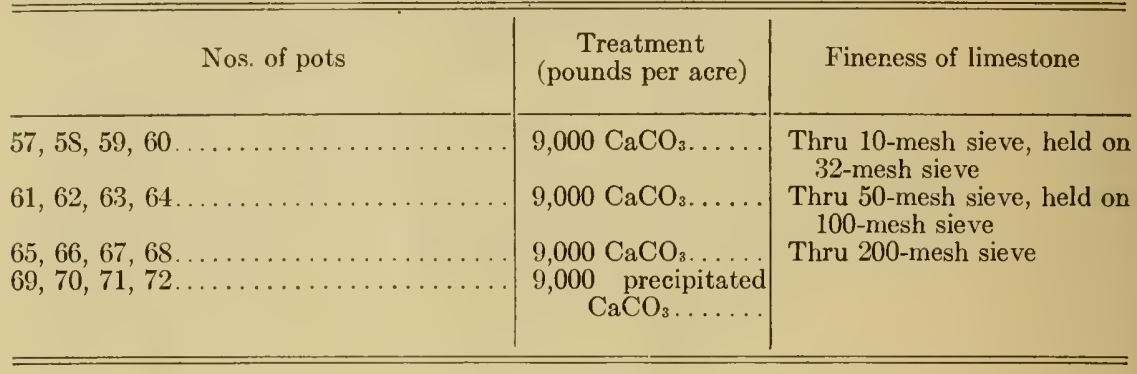

Experiment 3. Downward Movement of Burned Limestone thru Soll Cropped AND UNCROPPED

\begin{tabular}{|c|c|c|}
\hline Nos. of pots & $\begin{array}{c}\text { Treatment } \\
\text { (pounds per acre) }\end{array}$ & \\
\hline $\begin{array}{l}73,74,75,76 \ldots \\
77,78,79,80 \ldots\end{array}$ & $\begin{array}{l}3,000 \mathrm{CaO} \ldots \\
3,000 \mathrm{CaO} \ldots\end{array}$ & $\begin{array}{l}\text { Planted (oats) } \\
\text { Unplanted }\end{array}$ \\
\hline
\end{tabular}

\section{Experiments 1 and 2}

The pots included in experiments 1 and 2 were leached with distilled water equivalent to a yearly rainfall of thirty-six inches. Of these seventytwo pots the following were leached for six months: $5,6,7,8 ; 13,14,15$, $16 ; 21,22,23,24 ; 33,34,35,36 ; 41,42,43,44 ; 49,50,51,52$. All the others were leached for one year. The pots leached for six months and those leached for one year received a treatment of twenty-one and fortytwo liters of distilled water, respectively. The first treatment of water was applied to the pots on December 22, 1915. The dates and the amounts of the subsequent treatments are shown in table 2.

No water was applied after June 10 to the pots that were leached for six months. These pots were allowed to drain until June 28, which was just six months after the first drainage water had leached from them. The soil was then prepared for the analysis of total calcium as is described later. The pots leached for one year were sampled during the first week in January of 1917. 
Table 2. Date of Treatment and Amount of Distilled Water Applied to Pots OF EXPERIMENTS 1 AND 2

\begin{tabular}{|c|c|c|c|}
\hline \multirow{2}{*}{ No. of treatment } & \multirow{2}{*}{ Date } & \multicolumn{2}{|c|}{$\begin{array}{l}\text { Amount of water applied } \\
\text { (in cubic centimeters) }\end{array}$} \\
\hline & & $\begin{array}{l}\text { Pots leached } \\
\text { for six } \\
\text { months }\end{array}$ & $\begin{array}{l}\text { Pots leached } \\
\text { for trelve } \\
\text { months }\end{array}$ \\
\hline 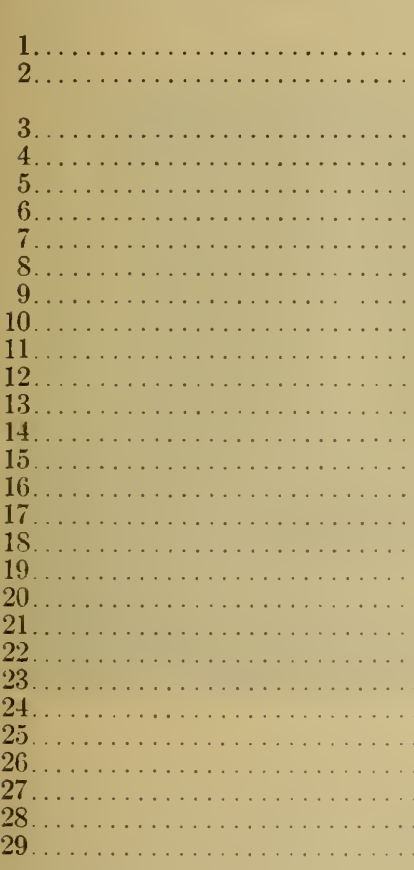 & $\begin{array}{l}1915 \\
\text { December } 22 \\
\text { December } 28 \\
1916 \\
\text { January } 5 \\
\text { January } 8 \\
\text { January } 18 \\
\text { February } 14 \\
\text { February } 21 \\
\text { March } 6 \\
\text { March } 20 \\
\text { April } 10 \\
\text { April } 24 \\
\text { May } 6 \\
\text { May } 8 \\
\text { May } 22 \\
\text { May } 29 \\
\text { June } 10 \\
\text { June } 27 \\
\text { July } 11 \\
\text { July } 27 \\
\text { August } 17 \\
\text { August } 31 \\
\text { October } 3 \\
\text { October } 10 \\
\text { October } 24 \\
\text { November } 6 \\
\text { November } 20 \\
\text { November } 22 \\
\text { December } 1 \\
\text { December } 10\end{array}$ & 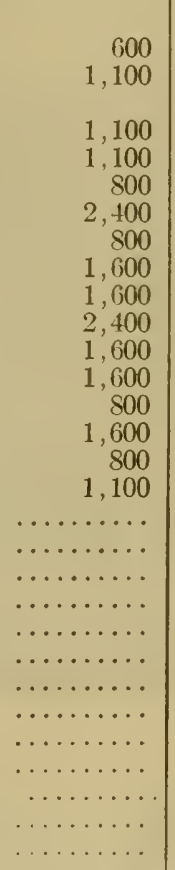 & $\begin{array}{r}600 \\
1,100 \\
1,100 \\
1,100 \\
800 \\
2,400 \\
800 \\
1,600 \\
1,600 \\
2,400 \\
1,600 \\
1,600 \\
800 \\
1,600 \\
800 \\
1,100 \\
1,600 \\
1,600 \\
1,600 \\
2,400 \\
1,600 \\
2,400 \\
800 \\
2,400 \\
1,600 \\
1,600 \\
800 \\
1,000 \\
1,600\end{array}$ \\
\hline Total. & & 21,000 & 42,000 \\
\hline
\end{tabular}

The drainage from the pots was collected in granite-ware pans, the pots being supported on wooden blocks (fig. 72). The water passed from the bottom of the pots thru round openings about one-half inch in diameter. To prevent the soil from washing thru these apertures, a small paraffined flowerpot was inverted over them before the soil was placed in the pots. 
This arrangement afforded excellent drainage. In all the experiments a quartz-sand mulch one-half inch thick, placed on the surface of the soil, prevented evaporation from the pots.

\section{Bicarbonate $\left(\mathrm{HCO}_{3}\right)$ content of the drainage water}

The amount of bicarbonate $\left(\mathrm{HCO}_{3}\right)$ contained in the drainage water from the pots leached for one year was determined frequently during the investigation. Samples for analysis were collected in small Erlenmeyer

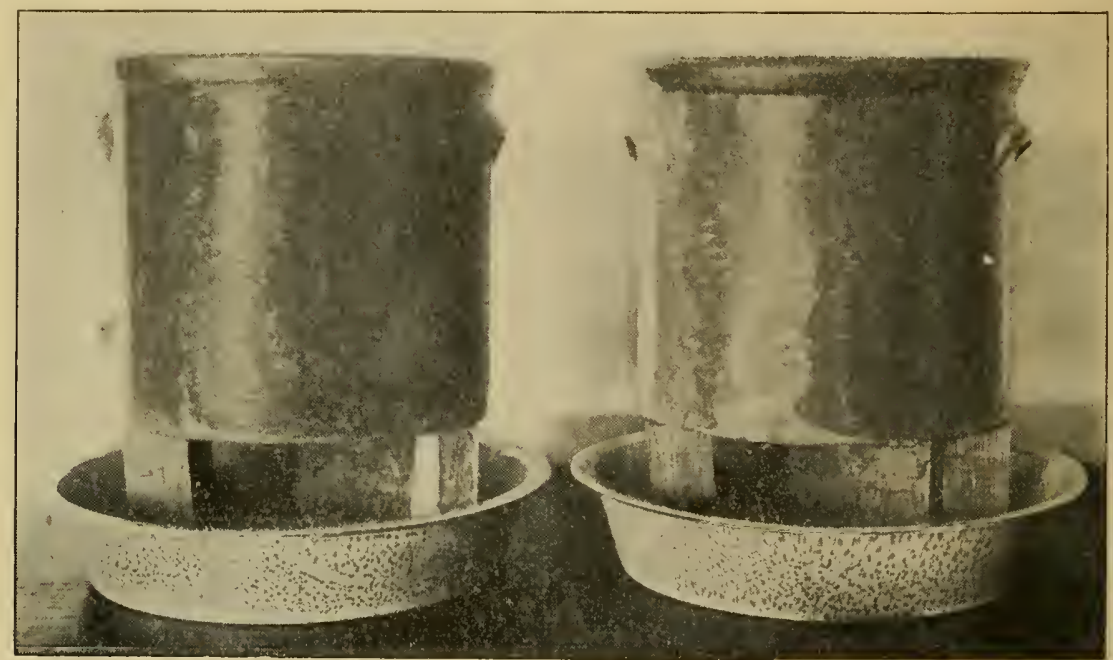

Fig. 72. ARrangement of POTS FOR LEACHING

flasks placed in such a manner as to catch the leachings as they came from the pots. It was evident that the bicarbonate content of the solutions would depend somewhat on the amount of percolation that had occurred immediately before the samples were collected for analysis, but this fact was not objectionable as the determinations were made only that some idea of the abundance of the bicarbonate in the leachings might be known.

It is seen from table 3 that the quantities of bicarbonate found in the drainage water from the pots, expressed in parts per million of solution, were sufficient to exert considerable influence on the solubility of the calcium oxid or calcium carbonate with which the pots were treated, and 
would lead one to believe that the water applied to the surface of the soil in the pots passed downward thru the soil, not between the soil and the sides of the pots.

Table 3. Bicarbonate $\left(\mathrm{HCO}_{3}\right)$ Content of Drainage Water from Pots Leached with Distilled Water for One Year.

(Average for similarly treated pots in parts per million of solution)

\begin{tabular}{|c|c|c|c|c|c|c|c|c|c|c|}
\hline \multirow{2}{*}{$\begin{array}{l}\text { Nos. } \\
\text { of pots }\end{array}$} & \multirow{2}{*}{$\begin{array}{c}\text { Treatment } \\
\text { (pounds per acre) }\end{array}$} & \multicolumn{9}{|c|}{ Date of collection of drainage water } \\
\hline & & $\begin{array}{r}\text { Jan. } \\
18\end{array}$ & $\begin{array}{c}\text { Feb. } \\
21\end{array}$ & $\underset{20}{\operatorname{Mar}}$ & $\begin{array}{l}\text { Apr. } \\
10\end{array}$ & $\begin{array}{l}\text { June } \\
10\end{array}$ & $\begin{array}{l}\text { July } \\
11\end{array}$ & Aug. & $\begin{array}{c}\text { Oct. } \\
3\end{array}$ & $\begin{array}{l}\text { Nov. } \\
6\end{array}$ \\
\hline \multirow{3}{*}{$\begin{array}{l}1 \text { to } 4 . \\
9 \text { to } 12 \\
17 \text { to } 20 .\end{array}$} & $3,000 \mathrm{CaO}$ & 139 & 112 & 110 & 74 & 162 & 155 & 56 & 42 & \\
\hline & $9,000 \mathrm{CaO}$ & $1 ?$ & 113 & 92 & 82 & 163 & 200 & 74 & 60 & 12 \\
\hline & $15,000 \mathrm{CaO}$ & 132 & 135 & 139 & 143 & 266 & 279 & 139 & 122 & 188 \\
\hline \multirow{3}{*}{$\begin{array}{l}29 \text { to } 32 . \\
37 \text { to } 40 \\
45 \text { to } 48 .\end{array}$} & $6,000 \mathrm{CaCO}_{3}$ & 144 & 112 & 82 & 56 & 121 & 121 & 41 & 39 & 77 \\
\hline & $18,000 \mathrm{CaCO}$ & 16 & 125 & 88 & 71 & 111 & 127 & 51 & 37 & \\
\hline & $30,000 \mathrm{C}$ & 141 & 130 & 113 & 82 & 91 & 82 & 55 & 34 & \\
\hline \multirow{3}{*}{$\begin{array}{l}57 \text { to } 60 . \\
61 \text { to } 64 .\end{array}$} & $9,000 \mathrm{CaCO}_{3}$, thru $10-$ & 109 & Q9 & 87 & 61 & 81 & 60 & 35 & 28 & \\
\hline & $9,000 \mathrm{CaCO}_{3}$, thru $50-$ & & 82 & & & 01 & 05 & 30 & 20 & \\
\hline & mesh, ............. & 83 & 71 & 55 & 58 & 53 & 51 & 30 & 21 & 32 \\
\hline \multirow{3}{*}{$\begin{array}{l}65 \text { to } 68 . \\
69 \text { to } 72 .\end{array}$} & $\begin{array}{r}9,000 \mathrm{CaCO}_{3}, \text { thru } 200- \\
\text { mesh } \ldots \ldots \ldots . . .\end{array}$ & 104 & 100 & 82 & 64 & 04 & 81 & 63 & 32 & \\
\hline & 9,000 precipitated & & & & & & & & & \\
\hline & $\mathrm{CaCO}_{3} \ldots \ldots \ldots \ldots$ & 128 & 115 & 91 & 68 & 92 & 81 & 44 & 30 & 39 \\
\hline
\end{tabular}

\section{Experiment 3}

As previously stated, the object of experiment 3 was to determine the effect of a crop on the downivard movement of calcium in soil. Eight pots were used for this purpose. The soil was placed in them in three layers, as has been described, and each pot received a treatment of burned limestone equivalent to an application of 3000 pounds to the acre. The experiment was begun on February 18, 1916, when four of the pots were planted to oats. Thirty seeds, which had been previously sterilized with a solution of calcium hypochlorite as suggested by Wilson (1915) were planted in each of the four pots, and the plants were thinned to twelve in a pot on February 26. The crop was harvested on July 18, just five months after it was planted and about the time when the grain 
was ripe. There was a good stand of oats on all the planted pots at the time when the crop was harvested.

The four unplanted pots were leached with distilled water at the same rate as were those in the foregoing experiments, which amounted to $17 \frac{1}{2}$ liters for five months. It was necessary to add more water to the pots on which the plants were grown, to make up for that lost by transpiration. During the period of growth $25 \frac{1}{2}$ liters of distilled water was applied to these pots. In table 4 are shown the amount of water applied to the planted and the umplanted pots from time to time during the experiment, and the dates of its application:

Table 4. Dates of Treatment and Amounts of Distilled Water Applied to Pots of Experiment 3

\begin{tabular}{|c|c|c|c|}
\hline \multirow{2}{*}{ No. of treatment } & \multirow{2}{*}{ Date } & \multicolumn{2}{|c|}{$\begin{array}{l}\text { Amount of water applied } \\
\text { (in cubic centimeters) }\end{array}$} \\
\hline & & $\begin{array}{l}\text { Planted } \\
\text { pots }\end{array}$ & $\begin{array}{l}\text { Unplanted } \\
\text { pots }\end{array}$ \\
\hline 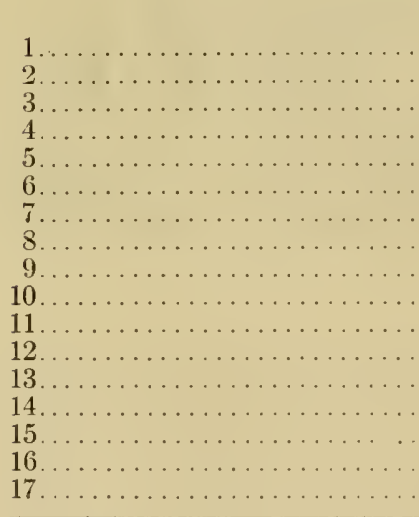 & \begin{tabular}{l}
\multicolumn{1}{c}{1916} \\
February 19 \\
February 26 \\
March 5 \\
March 11 \\
March 24 \\
April 10 \\
April 24 \\
May 4 \\
May 6 \\
May 13 \\
May 20 \\
May 26 \\
June 3 \\
June 14 \\
June 17 \\
June 27 \\
July 8
\end{tabular} & $\begin{array}{r}1,000 \\
800 \\
800 \\
1,000 \\
1,000 \\
1,600 \\
1,600 \\
800 \\
2,400 \\
800 \\
2,400 \\
800 \\
2,400 \\
800 \\
2,400 \\
2,400 \\
2,500\end{array}$ & $\begin{array}{r}1,000 \\
800 \\
800 \\
1,000 \\
1,000 \\
1,600 \\
1,600 \\
800 \\
800 \\
1,600 \\
1,600 \\
1,600 \\
1,600 \\
2,500\end{array}$ \\
\hline Total. & ( & 25,500 & 17,500 \\
\hline
\end{tabular}

\section{Method of sampling pots for analysis of calcium}

When the last application of water had drained from the pots, the quartz-sand mulch was removed from the surface of the soil and the pots 
were allowed to stand for several days in this condition until the soil was dry enough to be in a good workable condition. A large spatula was used to loosen the soil from the sides of the pots, and by this means it was possible, when inverting the pots, to slide the soil from them as a solid cylindrical mass (fig. 73). In order to guard against the possibility that calcium salts might have been carried down mechanically, during the course of the experiments, between the soil and the sides of the pots, the outside soil of the entire soil mass was removed with a knife, leaving what might be called an inner core of soil. This inner soil core was

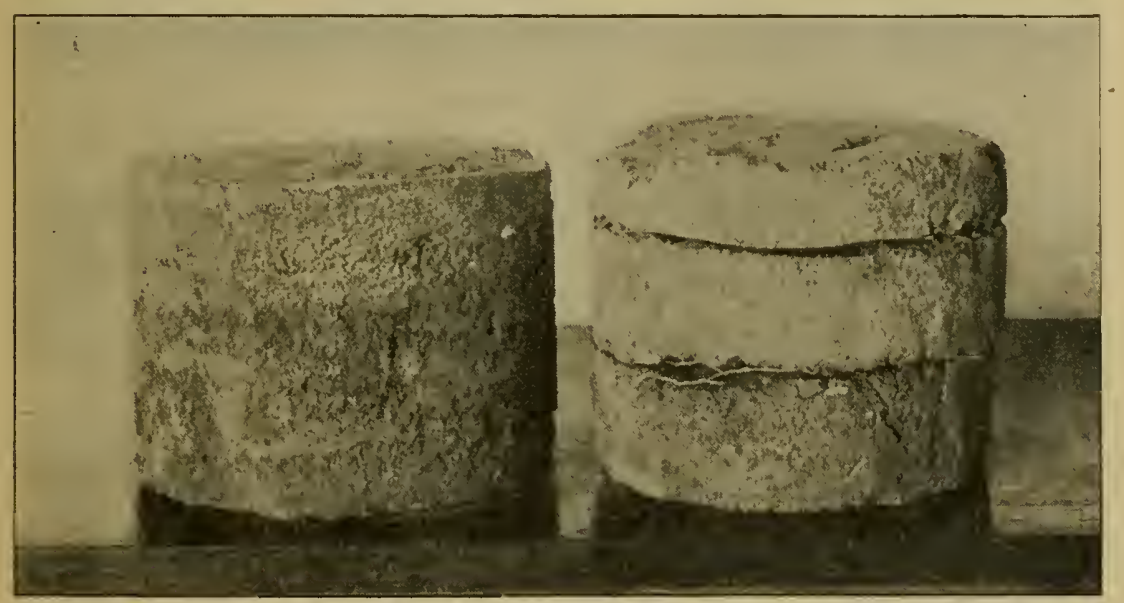

Fig. 73. CORES OF SOIL AS THEY CAME FROM THE POTS, BEFORE AND AFTER DIVISION

divided into three layers by inserting a spatula where the pieces of wire netting had been placed in the soil at the time when the pots were filled (fig. 74). The three layers thus obtained were placed in different receptacles, and a representative sample taken from each of them was air-dried. A portion of this air-clried sample was passed thru a 32-mesh sieve, oven-dried over night, and finally placed in an air-tight eight-ounce bottle, which was set aside until the soil could be analyzed for total calcium according to the method already described (page 304).

None of the soil layers into which some form of calcium had been placed were analyzed for this constituent at the end of the experiments, 


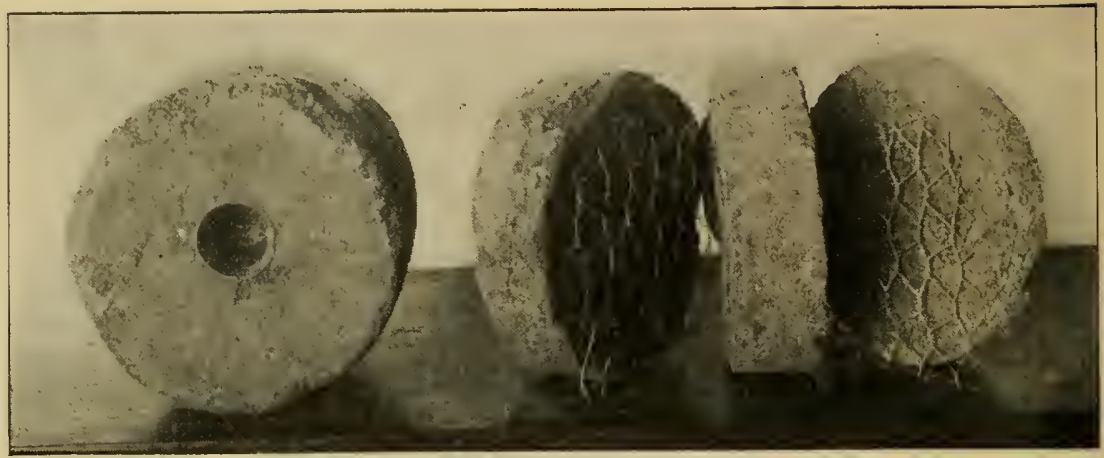

FIG. 74. LEFT: THE BOTTOM OF A CORE OF SOIL.

RIGHT: A CORE OF SOIL DIVIDED INTO ITS THREE LAYERS, SHOWING WIRE NETTING USED

but the amount of calcium present in them at the beginning of the experiments is given in tables 5 to 9 . The percentages of calcium found in the analyzed layers at the end of the experiments are taken as an indication of the translocation of this element thru the soil, and are also given in the tables.

Table 5. Experiment 1 - Percentages of Calcium in Second and Third Layers of Soll from Pots Leached with Distilled Water for Six Months

(Calcium treatments placed in first layer of soil)

\begin{tabular}{|c|c|c|c|c|c|c|c|}
\hline \multirow{3}{*}{$\begin{array}{l}\text { Treatment } \\
\text { (pounds } \\
\text { per acre) }\end{array}$} & \multirow{3}{*}{$\begin{array}{l}\text { No. } \\
\text { of } \\
\text { pot }\end{array}$} & \multicolumn{5}{|c|}{ Per cent of calcium in soil layers } & \multirow{3}{*}{$\begin{array}{l}\text { Treat- } \\
\text { ment } \\
\text { desig- } \\
\text { nation }\end{array}$} \\
\hline & & $\begin{array}{l}\text { Begin- } \\
\text { ning of } \\
\text { experi- }\end{array}$ & $\begin{array}{r}\text { Enc } \\
\text { exper }\end{array}$ & $\begin{array}{l}\text { of } \\
\text { ment }\end{array}$ & \multicolumn{2}{|c|}{ Arithmetic mean } & \\
\hline & & $\begin{array}{l}\text { First } \\
\text { layer }\end{array}$ & $\begin{array}{l}\text { Second } \\
\text { layei }\end{array}$ & $\begin{array}{l}\text { Third } \\
\text { layer }\end{array}$ & $\begin{array}{l}\text { Second } \\
\text { layer }\end{array}$ & $\begin{array}{l}\text { Third } \\
\text { layer }\end{array}$ & \\
\hline $3,000 \mathrm{CaO}$. & $\left\{\begin{array}{l}5 \\
6 \\
7 \\
8\end{array}\right\}$ & 0.69 & $\begin{array}{l}.37 \\
.40 \\
.33 \\
.38\end{array}$ & $\left.\begin{array}{l}.41 \\
.38 \\
.39 \\
.38\end{array}\right)$ & $.370 \pm .0098$ & $.390 \pm .0049$ & $\mathrm{~A}$ \\
\hline $6,000 \mathrm{CaCO}_{3}$. & $\left\{\begin{array}{l}33 \\
34 \\
35 \\
36\end{array}\right\}$ & 0.73 & $\begin{array}{l}.34 \\
.34 \\
.27 \\
.31\end{array}$ & $\begin{array}{l}.28 \\
.28 \\
.33 \\
.29\end{array}$ & $.315 \pm .0122$ & $.295 \pm .0085$ & $\mathrm{~A}$ \\
\hline
\end{tabular}


The Translocation of Calcium in a Soll

TABLE 5 (concluded)

\begin{tabular}{|c|c|c|c|c|c|c|c|}
\hline \multirow{3}{*}{$\begin{array}{l}\text { Treatment } \\
\text { (pounds } \\
\text { per acre) }\end{array}$} & \multirow{3}{*}{$\begin{array}{l}\text { No. } \\
\text { of } \\
\text { pot }\end{array}$} & \multicolumn{5}{|c|}{ Per cent of calcium in soil layers } & \multirow{3}{*}{$\begin{array}{l}\text { Treat- } \\
\text { ment } \\
\text { desig- } \\
\text { nation }\end{array}$} \\
\hline & & $\begin{array}{l}\text { Begin- } \\
\text { ning of } \\
\text { experi- }\end{array}$ & \multicolumn{2}{|c|}{$\begin{array}{c}\text { End of } \\
\text { experiment }\end{array}$} & \multicolumn{2}{|c|}{ Arithmetic mean } & \\
\hline & & $\begin{array}{l}\text { First } \\
\text { layer }\end{array}$ & $\begin{array}{c}\text { Second } \\
\text { layer }\end{array}$ & $\begin{array}{l}\text { Third } \\
\text { layer }\end{array}$ & $\begin{array}{l}\text { Second } \\
\text { layer }\end{array}$ & $\begin{array}{l}\text { Third } \\
\text { layer }\end{array}$ & \\
\hline $9,000 \mathrm{CaO}$. & $\left\{\begin{array}{l}13 \\
14 \\
15 \\
16\end{array}\right)$ & 1.41 & $\begin{array}{l}.37 \\
.31 \\
.39 \\
.35\end{array}$ & $\begin{array}{l}.32 \\
.32 \\
.33 \\
.35\end{array}$ & $.355 \pm .0122$ & $.330 \pm .0049$ & $\mathrm{~B}$ \\
\hline $18,000 \mathrm{CaCO}_{3}$ & $\left\{\begin{array}{l}41 \\
42 \\
43 \\
44\end{array}\right.$ & 1.54 & $\begin{array}{l}.33 \\
.29 \\
.32 \\
.32\end{array}$ & $\begin{array}{l}.33 \\
.31 \\
.33 \\
.33\end{array}$ & $.315 \pm .0061$ & $.325 \pm .0036$ & B \\
\hline $15,000 \mathrm{CaO}$. & $\left\{\begin{array}{l}21 \\
22 \\
23 \\
24\end{array}\right\}$ & 2.12 & $\begin{array}{l}.37 \\
.38 \\
.39 \\
.40\end{array}$ & $\begin{array}{l}.37 \\
.37 \\
.37 \\
.35\end{array}$ & $.385 \pm .0049$ & $.365 \pm .0036$ & C \\
\hline $30,000 \mathrm{CaCO}_{3}$ & $\left\{\begin{array}{l}49 \\
50 \\
51 \\
52\end{array}\right.$ & 2.33 & $\begin{array}{l}.30 \\
.33 \\
.29 \\
.32\end{array}$ & $\begin{array}{l}.31 \\
.35 \\
.32 \\
.38\end{array}$ & $.310 \pm .0073$ & $.340 \pm .0122$ & $\mathrm{C}$ \\
\hline
\end{tabular}


Table 6. Experiment 1 - Percentages of Calcium in Second and Third Layers of Soll from Pots Leached with Distilled Water for ONe Year

(Calcium treatments placed in first layer of soil)

\begin{tabular}{|c|c|c|c|c|c|c|c|}
\hline \multirow{3}{*}{$\begin{array}{l}\text { Treatment } \\
\text { (pounds } \\
\text { per acre) }\end{array}$} & \multirow{3}{*}{$\begin{array}{l}\text { No. } \\
\text { of } \\
\text { pot }\end{array}$} & \multicolumn{5}{|c|}{ Per cent of calcium in soil layers } & \multirow{3}{*}{$\begin{array}{l}\text { Treat- } \\
\text { ment } \\
\text { desig- } \\
\text { nation }\end{array}$} \\
\hline & & \multirow{2}{*}{$\begin{array}{c}\begin{array}{c}\text { Begin- } \\
\text { ning of } \\
\text { experi- } \\
\text { ment }\end{array} \\
\begin{array}{c}\text { First } \\
\text { layer }\end{array}\end{array}$} & \multicolumn{2}{|c|}{$\begin{array}{l}\text { End of } \\
\text { experiment }\end{array}$} & \multicolumn{2}{|c|}{ Arithmetic mean } & \\
\hline & & & $\begin{array}{l}\text { Second } \\
\text { layer }\end{array}$ & $\begin{array}{l}\text { Third } \\
\text { layer }\end{array}$ & $\begin{array}{l}\text { Second } \\
\text { layer }\end{array}$ & $\begin{array}{l}\text { Third } \\
\text { layer }\end{array}$ & \\
\hline $3,000 \mathrm{CaO}$. & $\left\{\begin{array}{l}1 \\
2 \\
3 \\
4\end{array}\right\}$ & 0.69 & $\left\{\begin{array}{l}.35 \\
.34 \\
.37 \\
.30\end{array}\right.$ & $\left.\begin{array}{l}.32 \\
.36 \\
.38 \\
.32\end{array}\right\}$ & $.340 \pm .0098$ & $.345 \pm .0122$ & D \\
\hline $6,000 \mathrm{CaCO}_{3}$ & $\left\{\begin{array}{l}29 \\
30 \\
31 \\
32\end{array}\right\}$ & 0.73 & $\begin{array}{l}.32 \\
.32 \\
.26 \\
.31\end{array}$ & $\left.\begin{array}{l}.25 \\
.30 \\
.29 \\
.33\end{array}\right)$ & $.303 \pm .0103$ & $.293 \pm .0109$ & $\mathrm{D}_{1}$ \\
\hline $9,000 \mathrm{CaO}$ & $\left\{\begin{array}{r}9 \\
10 \\
11 \\
12\end{array}\right\}$ & 1.41 & $\begin{array}{l}.30 \\
.33 \\
.30 \\
.29\end{array}$ & $\left.\begin{array}{l}.29 \\
.31 \\
.33 \\
.28\end{array}\right)$ & $.305 \pm .0061$ & $.303 \pm .0085$ & $\mathrm{E}$ \\
\hline $18,000 \mathrm{CaCO}_{3}$ & $\left\{\begin{array}{l}37 \\
38 \\
39 \\
40\end{array}\right\}$ & 1.54 & $\begin{array}{l}.33 \\
.33 \\
.32 \\
.30\end{array}$ & $\left.\begin{array}{l}.35 \\
.30 \\
.32 \\
.27\end{array}\right)$ & $.320 \pm .0049$ & $.310 \pm .0122$ & $\mathrm{E}_{\mathrm{s}}$ \\
\hline $15,000 \mathrm{CaO}$. & $\left\{\begin{array}{l}17 \\
18 \\
19 \\
20\end{array}\right)$ & 2.12 & $\begin{array}{l}.34 \\
.32 \\
.30 \\
.34\end{array}$ & $\left.\begin{array}{l}.39 \\
.30 \\
.34 \\
.33\end{array}\right)$ & $.325 \pm .0073$ & $.340 \pm .0122$ & $\mathrm{~F}$ \\
\hline $30,000 \mathrm{CaCO}_{3}$ & $\left(\begin{array}{l}45 \\
46 \\
47 \\
48\end{array}\right)$ & 2.33 & $\begin{array}{l}.31 \\
.29 \\
.30 \\
.27\end{array}$ & $\left.\begin{array}{l}27 \\
.27 \\
.27 \\
.28\end{array}\right)$ & $.293 \pm .0061$ & $.273 \pm .0019$ & $\mathrm{~F}_{1}$ \\
\hline
\end{tabular}


The Translocation of Calcium in a Soll

Table 7. Experiment 1 - Percentages of Calcium in First and Second Layers of Soll from Pots Leached with Distilled Water for One Year

(Calcium treatments placed in third layer of soil)

\begin{tabular}{|c|c|c|c|c|c|c|c|}
\hline \multirow{3}{*}{$\begin{array}{l}\text { Treatment } \\
\text { (pounds } \\
\text { per acre) }\end{array}$} & \multirow{3}{*}{$\begin{array}{l}\text { No. } \\
\text { of } \\
\text { pot }\end{array}$} & \multicolumn{5}{|c|}{ Per cent of calcium in soil layers } & \multirow{3}{*}{$\begin{array}{l}\text { Treat- } \\
\text { ment } \\
\text { desig- } \\
\text { nation }\end{array}$} \\
\hline & & \multirow{2}{*}{$\begin{array}{c}\begin{array}{c}\text { Begin- } \\
\text { ning of } \\
\text { experi- } \\
\text { ment }\end{array} \\
\begin{array}{l}\text { Third } \\
\text { layer }\end{array}\end{array}$} & \multicolumn{2}{|c|}{$\begin{array}{l}\text { End of } \\
\text { experiment }\end{array}$} & \multicolumn{2}{|c|}{ Arithmetic mean } & \\
\hline & & & $\begin{array}{l}\text { First } \\
\text { layer }\end{array}$ & $\begin{array}{c}\text { Second } \\
\text { layer }\end{array}$ & $\begin{array}{l}\text { First } \\
\text { layer }\end{array}$ & $\begin{array}{l}\text { Second } \\
\text { layer }\end{array}$ & \\
\hline $15,000 \mathrm{CaO}$ & $\left\{\begin{array}{l}25 \\
26 \\
27 \\
28\end{array}\right\}$ & 2.12 & $\begin{array}{l}.32 \\
.32 \\
.34 \\
.29\end{array}$ & $\left.\begin{array}{l}.30 \\
.33 \\
.35 \\
.28\end{array}\right\}$ & $.318 \pm .0066$ & $.315 \pm .0122$ & G \\
\hline $30,000 \mathrm{CaCO}_{3}$ & $\left\{\begin{array}{l}53 \\
54 \\
55 \\
56\end{array}\right\}$ & 2.33 & $\begin{array}{l}.29 \\
.29 \\
.31 \\
.31\end{array}$ & $\left.\begin{array}{l}.35 \\
.32 \\
.28 \\
.30\end{array}\right\}$ & $.300 \pm .0049$ & $.313 \pm .0109$ & $\mathrm{G}_{1}$ \\
\hline
\end{tabular}

Table 8. Experiment 2-Percentages of Calcium in Second and Third layers of Soll from Pots Leached with Distilled Water for ONe Year

(Calcium treatments placed in first layer of soil)

\begin{tabular}{|c|c|c|c|c|c|c|c|c|}
\hline \multirow{3}{*}{$\begin{array}{l}\text { Treatment } \\
\text { (pounds } \\
\text { per acre) }\end{array}$} & \multirow{3}{*}{$\begin{array}{l}\text { Fineness } \\
\text { of } \\
\text { limestone }\end{array}$} & \multirow{3}{*}{$\begin{array}{c}\text { No. of } \\
\text { pot }\end{array}$} & \multicolumn{5}{|c|}{ Per cent of caleium in soil layers } & \multirow{3}{*}{$\begin{array}{l}\text { Treat- } \\
\text { ment } \\
\text { desig- } \\
\text { nation }\end{array}$} \\
\hline & & & \multirow{2}{*}{$\begin{array}{c}\begin{array}{c}\text { Begin- } \\
\text { ning of } \\
\text { experi- } \\
\text { ment }\end{array} \\
\begin{array}{c}\text { First } \\
\text { layer }\end{array} \\
\end{array}$} & \multicolumn{2}{|c|}{$\begin{array}{c}\text { Fnd of } \\
\text { experiment }\end{array}$} & \multicolumn{2}{|c|}{ Arithmetic mean } & \\
\hline & & & & $\begin{array}{l}\text { Serond } \\
\text { layer }\end{array}$ & $\begin{array}{l}\text { Third } \\
\text { layer }\end{array}$ & $\begin{array}{l}\text { Second } \\
\text { layer }\end{array}$ & $\begin{array}{l}\text { Third } \\
\text { layer }\end{array}$ & \\
\hline $9,000 \mathrm{CaCO}_{3}$ & $\begin{array}{l}\text { Thru 10-mesh, } \\
\text { held on 32- } \\
\text { mesh }\end{array}$ & $\left\{\begin{array}{l}57 \\
58 \\
59 \\
60\end{array}\right\}$ & 0.91 & $\begin{array}{l}.36 \\
.30 \\
.32 \\
.33 \\
\end{array}$ & $\left.\begin{array}{l}.32 \\
.33 \\
.35 \\
.31\end{array}\right\}$ & $.328 \pm .0085$ & $.328 \pm .0061$ & $\mathrm{H}$ \\
\hline $9,000 \mathrm{CaCO}_{3}$ & $\begin{array}{l}\text { Thru 50-miesh, } \\
\text { held on 100- } \\
\text { mesh }\end{array}$ & $\left\{\begin{array}{l}61 \\
62 \\
63 \\
64\end{array}\right\}$ & 0.91 & $\begin{array}{l}.28 \\
.30 \\
.29 \\
\end{array}$ & $\left.\begin{array}{l}.27 \\
.25 \\
.26\end{array}\right\}$ & $.285 \pm .0049$ & $.265 \pm .0049$ & I \\
\hline $9,000 \mathrm{CaCO}_{3}$ & Thru 200-mesh & $\left\{\begin{array}{l}65 \\
66 \\
67 \\
68\end{array}\right\}$ & 0.91 & $\begin{array}{l}.29 \\
.32 \\
.27 \\
.31 \\
\end{array}$ & $\left.\begin{array}{l}.28 \\
.29 \\
29\end{array}\right\}$ & $.298 \pm .0085$ & $.295 \pm .0061$ & $\mathbf{J}$ \\
\hline $9,000 \mathrm{CaCO}_{3}$ & $\begin{array}{l}\text { Precipitated } \\
\mathrm{CaCO}_{3}\end{array}$ & $\left\{\begin{array}{l}69 \\
70 \\
71 \\
72\end{array}\right\}$ & 0.91 & $\begin{array}{l}.33 \\
.28 \\
.35 \\
.28\end{array}$ & $\left.\begin{array}{l}.29 \\
.28 \\
.29\end{array}\right\}$ & $.310 \pm .0146$ & $.298 \pm .0081$ & $\mathrm{~K}$ \\
\hline
\end{tabular}


Table 9. Experiment 3 - Percentages of Calcium in Second and Third Layers of Cropped and Uncropped Sorl from Pots Leached with Distilled Water for Five Months

(Calcium treatments placed in first layer of soil)

\begin{tabular}{|c|c|c|c|c|c|c|c|c|}
\hline \multirow{3}{*}{$\begin{array}{l}\text { Treatment } \\
\text { (pounds } \\
\text { per acre) }\end{array}$} & \multirow{3}{*}{$\begin{array}{c}\text { Planted } \\
\text { or } \\
\text { unplanted }\end{array}$} & \multirow{3}{*}{$\begin{array}{c}\text { No. of } \\
\text { pot }\end{array}$} & \multicolumn{5}{|c|}{ Per cent of calcium in soil layers } & \multirow{3}{*}{$\begin{array}{l}\text { Treat- } \\
\text { ment } \\
\text { desig- } \\
\text { nation }\end{array}$} \\
\hline & & & $\begin{array}{l}\text { Begin- } \\
\text { ning of } \\
\text { experi- }\end{array}$ & \multicolumn{2}{|c|}{$\begin{array}{l}\text { End of } \\
\text { experinient }\end{array}$} & \multicolumn{2}{|c|}{ Arithmetic mean } & \\
\hline & & & $\begin{array}{l}\text { First } \\
\text { layer }\end{array}$ & $\begin{array}{l}\text { Second } \\
\text { layer }\end{array}$ & $\begin{array}{l}\text { Third } \\
\text { layer }\end{array}$ & $\begin{array}{l}\text { Second } \\
\text { layer }\end{array}$ & $\begin{array}{l}\text { Third } \\
\text { layer }\end{array}$ & \\
\hline $3,000 \mathrm{CaO}$ & Planted (oats) & $\left\{\begin{array}{l}73 \\
74 \\
75 \\
76\end{array}\right\}$ & 0.58 & $\left\{\begin{array}{l}.21 \\
.20 \\
.19 \\
.24 \\
\end{array}\right.$ & $\left.\begin{array}{l}.18 \\
.24 \\
.22\end{array}\right\}$ & $.210 \pm .0073$ & $.218 \pm .0090$ & $\mathbf{L}$ \\
\hline $3,000 \mathrm{CaO}$ & Unplanted & $\left\{\begin{array}{l}77 \\
78 \\
79 \\
80\end{array}\right\}$ & 0.58 & $\left\{\begin{array}{l}\cdot .18 \\
.22 \\
.20 \\
.18\end{array}\right.$ & $\left.\begin{array}{r}.22 \\
.19 \\
.23\end{array}\right\}$ & $.195 \pm .00 \div 3$ & $.205 \pm .0098$ & $\mathrm{~L}_{1}$ \\
\hline
\end{tabular}

\section{INTERPRETATION OF ANALYTICAL DATA}

The amounts of calcium present in the analyzed layers of soil at the end of the experiments, from the pots that had received the same calcium treatment, varied to some extent, as is seen from tables 5 to 9 . The variation in the calcium content of the soil from pots similarly treated appears to be about as great as that shown by a comparison of differently treated pots. In view of this fact, it became necessary to determine the experimental error of the investigation, before any definite conclusions could be drawn regarding the movement of calcium thru the soil, in relation to the following points: (1) Did the analyzed soil layers contain more calcium at the end of the experiments than was contained in the original soils at the beginning of the investigation? (2) Did the layer of soil adjoining the one treated with calcium contain more of this element than the layer farther removed? (3) If calcium had moved thru the soil, did the degree of movement vary with smaller or larger applications of this constituent? In order to draw conclusions accurately from the data presented, the arithmetical mean value with its probable error, for the amount of calcium present in the soil layers resulting from different calcium treatments, was determined. These values are given in the tables and are used in interpreting the results of the investigation. For 
convenience the letters in the extreme right-hand column of each table are used to designate the different pot treatments.

Peter's formula as given by Mellor (1909) was used in determining the probable errors. According to this formula the probable error, $R$, of the arithmetical mean of a series of observations is

$$
\mathrm{R}= \pm 0.8453 \frac{\underline{\mathrm{n}}(+\mathrm{v})}{\mathrm{n}}
$$

in which $\Sigma(+v)$ denotes the sum of the deviations of every observation from the mean, their sign being disregarded, and $n$ denotes the number of observations actually made. The increase of calcium in one layer of soil over that in another layer, in pots similarly or dissimilarly treated, or the amount of calcium present in the soil from a calcium-treated pot over that in the original soil at the beginning of the experiment, can be determined by subtracting the arithmetical mean value of calcium for any one particular soil from that for any other soil, the probable error of the difference being derived from the formula

$$
\mathrm{E}=\sqrt{\mathrm{E}_{1^{2}}+\mathrm{E}_{2}^{2}}
$$

in which $\mathrm{E}_{1}$ is the probable error of one mean, and $\mathrm{E}_{2}$ the probable error of the other. This procedure is followed in explaining the results of the experiments shown in tables 5 to 9 .

A comparison of the amounts of calcium found by analysis in the analyzed soil layers from pots that were similarly treated is given in table 10, which was compiled from the data given in tables 5 to 9 inclusive. This table shows that in eleven cases out of twenty there was a greater amount of calcium in the layer of soil adjoining the one that had been treated with calcium, that in eight of the cases the soil layer farther removed from the treated layer contained the greater percentage of calcium, and that in one case there was an equal amount of ealcium in each of the untreated soil layers. The differences in the amounts of calcium in the two soil layer's are not great enough to be of any consequence, however. Wood and Stratton (1910) have shown that in order to be significant, differences resulting from different treatments should be at least 3.8 times their probable error, corresponding to odds of 30 to 1 that such differences are real and not due to normal variation. As none of the differences appearing in table 10 are sigmificant, it is safe to con- 
clude that the soil layers which were analyzed did not differ in their calcium content for any one particular treatment. This being true, the remainder of the discussion of the results may be confined to a consideration of the soil layer adjacent to the layer receiving the calcium treatment. In every case, regardless of the position of the calcium-treated layers in the pots, this is the second layer of soil.

Table 10. Comparison of the Amounts of Calcium in the Analyzed layers of Sorl from Pots Similarly Treated

(For the differences to be significant, the mean must be 3.8 times the probable error)

\begin{tabular}{|c|c|c|c|c|}
\hline Treatment & $\begin{array}{l}\text { Difference } \\
\text { in amounts } \\
\text { of calcium }\end{array}$ & $\begin{array}{l}\text { Layer } \\
\text { having } \\
\text { the greater } \\
\text { amount of } \\
\text { calcium }\end{array}$ & $\begin{array}{l}\text { Duration of } \\
\text { experiment }\end{array}$ & $\begin{array}{l}\text { No. of } \\
\text { experi- } \\
\text { ment }\end{array}$ \\
\hline 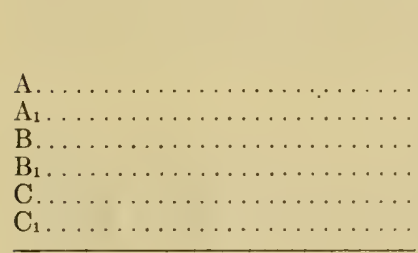 & $\begin{array}{c}\text { In second and } \\
\text { third layers } \\
.020 \pm .0109 \\
.020 \pm .0147 \\
.025 \pm .0131 \\
.010 \pm .0071 \\
.020 \pm .0061 \\
.030 \pm .0142\end{array}$ & $\begin{array}{l}\text { Third } \\
\text { Second } \\
\text { Second } \\
\text { Third } \\
\text { Second } \\
\text { Third }\end{array}$ & Six months & \multirow{3}{*}{1} \\
\hline $\begin{array}{l}\mathrm{D} \\
\mathrm{D}_{1} \ldots \ldots \ldots \\
\mathrm{E} \\
\mathrm{E} \\
\mathrm{E}_{1} \ldots \ldots \ldots \\
\mathrm{F} \\
\mathrm{F} \\
\mathrm{F}_{1} \ldots \ldots \ldots\end{array}$ & $\begin{array}{l}.005 \pm .0156 \\
.010 \pm .0149 \\
.002 \pm .0104 \\
.010 \pm .0131 \\
.015 \pm .0142 \\
.020 \pm .0064\end{array}$ & $\begin{array}{l}\text { Third } \\
\text { Second } \\
\text { Second } \\
\text { Second } \\
\text { Third } \\
\text { Second }\end{array}$ & \multirow[t]{2}{*}{ Twelve months } & \\
\hline $\begin{array}{l}\mathrm{G} \ldots \ldots \ldots \ldots \ldots \ldots \ldots \ldots \ldots \ldots \ldots \ldots \ldots \\
\mathrm{G}_{1} \ldots \ldots \ldots \ldots \ldots \ldots \ldots \ldots\end{array}$ & $\begin{array}{l}\text { In first and } \\
\text { second layers } \\
.003 \pm .0138 \\
.013 \pm .0119\end{array}$ & $\begin{array}{l}\text { First } \\
\text { Second }\end{array}$ & & \\
\hline 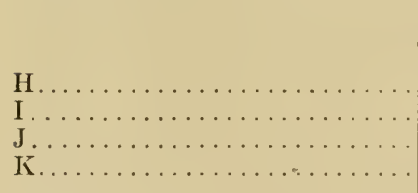 & $\begin{array}{l}\text { In second and } \\
\text { third layers } \\
.000 \pm .0104 \\
.020 \pm .0069 \\
.003 \pm .0104 \\
.012 \pm .0167\end{array}$ & $\begin{array}{l}\text { Second } \\
\text { Second } \\
\text { Second }\end{array}$ & Twelve months & 2 \\
\hline $\begin{array}{l}\mathrm{L} \\
\mathrm{L} \\
\mathrm{L}_{1} \ldots \ldots \ldots \ldots \ldots \ldots \ldots \ldots \ldots \ldots \ldots \ldots \ldots \ldots \ldots \ldots\end{array}$ & $\begin{array}{l}.008 \pm .0116 \\
.010 \pm .0122\end{array}$ & $\begin{array}{l}\text { Third } \\
\text { Third }\end{array}$ & Five months & 3 \\
\hline
\end{tabular}




\section{Results of experiment 1}

The differences in the percentage of calcium in the second layer of soil, resulting from different calcium treatments, are shown in table 11. It is evident from this table that in the one case when the mean is greater than 3.8 times the probable error, the soil from the pots receiving treat-

Table 11. Comparison of the Amounts of Calcium in the Second Layer of Soll from Pots Differentuy Treated in Experiment 1

(For the differences to be significant, the mean must be 3.8 times the probable error)

\begin{tabular}{|c|c|c|c|c|c|}
\hline $\begin{array}{l}\text { Treatments } \\
\text { compared }\end{array}$ & $\begin{array}{l}\text { Difference in } \\
\text { amounts of } \\
\text { calcium in } \\
\text { second layer } \\
\text { of soil }\end{array}$ & $\begin{array}{c}\text { Treat- } \\
\text { ment } \\
\text { showing } \\
\text { greater } \\
\text { amount of } \\
\text { calcium }\end{array}$ & $\begin{array}{l}\text { Duration of } \\
\text { experi- } \\
\text { ment }\end{array}$ & $\begin{array}{l}\text { Layer of } \\
\text { soil in } \\
\text { which } \\
\text { calcium } \\
\text { was placed }\end{array}$ & $\begin{array}{l}\text { Calcium } \\
\text { treatments } \\
\text { compared }\end{array}$ \\
\hline $\begin{array}{l}A \text { and } A_{1} \ldots \ldots \\
B \text { and } B_{1} \ldots \\
C \text { and } C_{1} \ldots \ldots\end{array}$ & $\begin{array}{l}.055 \pm .0156 \\
.040 \pm .0137 \\
.075 \pm .0088\end{array}$ & $\begin{array}{l}\mathrm{A} \\
\mathrm{B} \\
\mathrm{C}\end{array}$ & Six months & \multirow{2}{*}{ First } & \multirow{2}{*}{$\begin{array}{l}\text { Equivalent } \\
\text { quantities of } \\
\mathrm{CaO} \text { and } \\
\mathrm{CaCO}_{3}\end{array}$} \\
\hline $\begin{array}{l}D \text { and } D_{1} \ldots \ldots \\
E \text { and } E_{1} \ldots \ldots \\
F \text { and } F_{1} \ldots \ldots\end{array}$ & $\begin{array}{l}.037 \pm .0142 \\
.015 \pm .0078 \\
.032 \pm .0095\end{array}$ & $\begin{array}{l}\mathrm{D} \\
\mathrm{E}_{1} \\
\mathrm{~F}\end{array}$ & $\begin{array}{l}\text { Twelve } \\
\text { months }\end{array}$ & & \\
\hline $\begin{array}{l}A \text { and } B \ldots \ldots \\
A \text { and } C \ldots \ldots \\
B \text { and } C \ldots \ldots\end{array}$ & $\begin{array}{l}.015 \pm .0156 \\
.015 \pm .0109 \\
.030 \pm .0131\end{array}$ & $\begin{array}{l}\mathrm{A} \\
\mathrm{C} \\
\mathrm{C}\end{array}$ & Six months & \multirow{2}{*}{ First } & \multirow{2}{*}{$\begin{array}{l}\text { D i ff e r e n t } \\
\text { quantities of } \\
\mathrm{CaO}\end{array}$} \\
\hline $\begin{array}{l}\mathrm{D} \text { and } \mathrm{E} \ldots \ldots \\
\mathrm{D} \text { and } \mathrm{F} \ldots \ldots \\
\mathrm{E} \text { and } \mathrm{F} \ldots \ldots\end{array}$ & $\begin{array}{l}.035 \pm .0115 \\
.015 \pm .0122 \\
.020 \pm .0095\end{array}$ & $\begin{array}{l}\mathrm{D} \\
\mathrm{D} \\
\mathrm{F}\end{array}$ & $\begin{array}{l}\text { Twelve } \\
\text { months }\end{array}$ & & \\
\hline $\mathrm{G}$ and $\mathrm{G}_{1} \ldots \ldots$ & $.002 \pm .0163$ & $\mathrm{G}$ & $\begin{array}{l}\text { Twelve } \\
\text { months }\end{array}$ & Third & $\begin{array}{l}\text { Equivalent } \\
\text { quantities of } \\
\mathrm{CaO} \text { and } \\
\mathrm{CaCO}_{3}\end{array}$ \\
\hline
\end{tabular}

ment $\mathrm{C}$ contained more calcium in the second layer than did the soil from the pots receiving treatment $\mathrm{C}_{1}$. $\mathrm{C}$ being greater than $\mathrm{C}_{1}$, and the difference between $A$ and $A_{1}$ being almost without the experimental error, it appears that the second layer of soil from the pots that were leached for six months contained more calcium when the first layer had been treated with burned limestone than when the first layer had received a treatment of ground limestone. When the soil with similar treatments 
was leached for twelve months, this relationship between the burned and the ground limestone treatments is not shown, as can be seen from the table. It seems reasonable to believe that the results from the soil that was leached for the longer period are nearer the truth, as this soil had a longer time in which to become adjusted to the conditions of the experiment. If this assumption is true, it can be concluded from the results given in table 11 that the burned limestone did not move downward in the soil more rapidly than did the ground limestone. The table also reveals the fact that there was no more calcium present in the second layer of soil resulting from larger applications of burned limestone than there was from smaller applications of this substance, and that there was no appreciable difference between the amounts of calcium present in the second layer of soil from the pots that had been treated with either burned limestone or ground limestone in the third layer.

The question now arising is whether or not the amounts of calcium present in the second layer of soil from the pots in experiment 1 which were treated with burned limestone (since the tendency was for the pots treated with burned limestone to contain more calcium in the second soil layer than those treated with ground limestone) are large enough, when compared with the amount of calcium in the soil at the beginning

TABLE 12. Comparison of the Amounts of Calcium Found in the Second Layer op Soll at the End of Experiment 1, with the Amount Present in the Soil at the BeginNing OF THE EXPERIMENT

(For the differences to be significant, the mean must be 3.8 times the probable error)

\begin{tabular}{|c|c|c|c|c|}
\hline Treatment & $\begin{array}{l}\text { Calcium } \\
\text { present in } \\
\text { second layer } \\
\text { of soil } \\
\text { at end of } \\
\text { experiment }\end{array}$ & $\begin{array}{l}\text { Calcium } \\
\text { present in } \\
\text { soil at } \\
\text { beginning of } \\
\text { experiment }\end{array}$ & $\begin{array}{l}\text { Difference } \\
\text { in calcium }\end{array}$ & $\begin{array}{l}\text { Duration of } \\
\text { experiment }\end{array}$ \\
\hline $\begin{array}{l}\mathrm{A} \ldots \ldots \ldots \ldots \ldots \ldots \\
\mathrm{B} \\
\mathrm{C} \ldots \ldots \ldots \ldots \ldots \ldots\end{array}$ & $\left.\begin{array}{l}.370 \pm .0098 \\
.355 \pm .0122 \\
.385 \pm .0049\end{array}\right\}$ & $.328 \pm .0156$ & $\left\{\begin{array}{l}.042 \pm .0184 \\
.027 \pm .0198 \\
.057 \pm .0164\end{array}\right.$ & Six months \\
\hline $\begin{array}{l}\mathrm{D} \ldots \ldots \ldots \ldots \\
\mathrm{E} \ldots \ldots \ldots \ldots \ldots \\
\mathrm{F} \\
\mathrm{G} \ldots \ldots \ldots \ldots \ldots \ldots\end{array}$ & $\begin{array}{l}.340 \pm .0098 \\
.305 \pm .0061 \\
.325 \pm .0073 \\
.318 \pm .0066\end{array}$ & $.328 \pm .0156$ & $\left\{\begin{array}{l}.012 \pm .0184 \\
.023 \pm .0168 \\
.003 \pm .0172 \\
.010 \pm .0169\end{array}\right.$ & Twelve months \\
\hline
\end{tabular}


of the experiment, to show that there was an upward or a downward movement of this constituent during the course of the experiment. Such a comparison is made in table 12 . Treatment $\mathrm{C}$ shows a downward, movement of calcium into the second soil layer that is almost within certainty; but since treatments $\mathrm{A}, \mathrm{B}, \mathrm{D}, \mathrm{E}$, and $\mathrm{F}$ do not indicate such a movement, it can be concluded that there has been no downward movement of calcium within the soil. No upward movement of calcium resulted from treatment $\mathrm{G}$, as can be seen from the table.

\section{Results of experiments 2 and 3}

The results of experiments 2 and 3 are interpreted in the same way as are those of experiment 1 , and are summarized in tables 13 and 14 :

Table 13. Comparison of the Amounts of Calcium Found in the Second Layer of Soll at the End of Experiment 2, with the Amount Present in the Soil at the Beginning of the Experiment

(Limestone added in equal amounts. For the differences to be significant, the mean must be 3.8 times the probable error)

\begin{tabular}{|c|c|c|c|c|c|c|}
\hline $\begin{array}{l}\text { Treat- } \\
\text { ment }\end{array}$ & $\begin{array}{l}\text { Calcium } \\
\text { present in } \\
\text { second layer } \\
\text { of soil } \\
\text { at end of } \\
\text { experiment }\end{array}$ & $\begin{array}{l}\text { Calcium } \\
\text { present in } \\
\text { soil at } \\
\text { beginning of } \\
\text { experiment }\end{array}$ & $\begin{array}{l}\text { Difference } \\
\text { in calcium }\end{array}$ & $\begin{array}{c}\text { Duration } \\
\text { of } \\
\text { experi- } \\
\text { ment }\end{array}$ & $\begin{array}{l}\text { Layer } \\
\text { of soil } \\
\text { in which } \\
\text { calcium } \\
\text { was } \\
\text { placed }\end{array}$ & $\begin{array}{l}\text { Fineness of lime- } \\
\text { stone applied }\end{array}$ \\
\hline $\mathrm{H}$ & $.328 \pm .0085$ & \multirow{4}{*}{$.300+.0154$} & $.028 \pm .0176$ & \multirow{4}{*}{$\begin{array}{l}\text { Twelve } \\
\text { months }\end{array}$} & \multirow{4}{*}{ First } & \multirow{4}{*}{$\begin{array}{l}\text { H-Thru 10-mesh } \\
\text { sieve, held on } 32- \\
\text { mesh } \\
\text { I-Thru } 50 \text {-mesh } \\
\text { sieve, held on 100- } \\
\text { mesh } \\
\text { J-Thru 200-mesh } \\
\text { sieve } \\
\text { K- - Precipitated } \\
\mathrm{CaCO}_{3}\end{array}$} \\
\hline I & $.285 \pm .0049$ & & $.015 \pm .0162$ & & & \\
\hline $\mathbf{J}$ & $.298 \pm .0085$ & & $.002 \pm .0176$ & & & \\
\hline א & $.310 \pm .0146$ & & $.010 \pm .0212$ & & & \\
\hline
\end{tabular}

There was no movement of calcium from the first to the second layer of soil in the pots that were treated with ground limestone at the rate of 9000 pounds to the acre, regardless of the fineness to which the limestone had been ground, nol with an equivalent quantity of precipitated calcium carbonate. This fact is well brought out by the figures in table 13. The differences shown in the table between the amount of calcium in the soil at the beginning of the experiment and that found in the second soil layer at the end of the experiment are not great enough to indicate any movement of this element. 
In table 14 it is shown clearly that growing oats on the potted soil treated with burned limestone at the rate of 3000 pounds to the acre had no influence on the downward movement of ealcium thru the soil. There was no movement of calcium in the soil either with or without the growth

Table 14. Comparison of the Amounts of Calcrum in the Second Layer of Soil from Planted and Unplanted Pots in Experiment 3

(Calcium added in equal amounts as burned limestone. For the differences to be significant, the mean must be 3.8 times the probable error)

\begin{tabular}{l|c|c|c|c}
\hline \multicolumn{1}{c|}{ Treatments compared } & $\begin{array}{c}\text { Difference } \\
\text { in amounts } \\
\text { of calcium in } \\
\text { second layer } \\
\text { of soil }\end{array}$ & $\begin{array}{c}\text { Treatment } \\
\text { showing } \\
\text { greater } \\
\text { amount of } \\
\text { calcium }\end{array}$ & $\begin{array}{c}\text { Duration } \\
\text { of } \\
\text { experiment }\end{array}$ & $\begin{array}{c}\text { Layer of } \\
\text { soil in } \\
\text { which } \\
\text { calcium } \\
\text { was placed }\end{array}$ \\
\hline $\mathrm{L}$ and $\mathrm{L}_{1} \ldots \ldots \ldots \ldots \ldots \ldots \ldots \ldots \ldots \ldots \ldots \ldots$ & $015 \pm .0103$ & $\mathrm{~L}$ & Five months & First \\
\hline $\mathrm{L}$ and $\mathrm{Z}^{*} \ldots \ldots \ldots \ldots \ldots \ldots \ldots$ & $\mathrm{Z}$ & & \\
\hline \hline
\end{tabular}

$* \mathrm{Z}$ (o:irinal soil $)=.220 \pm .0049$

of plants, as is shown by a comparison of the calcium present in the second soil layer at the end of the experiment with that present in the soil at the time when the experiment was begun.

\section{SUMMARY}

Calcium applied to a clayey silt loam soil in the form of burned limestone, ground limestone, or precipitated calcium carbonate, did not move downward in the soil to any appreciable extent when the soil was leached in pots for one year with distilled water.

The soil from some of the pots that were leached for six months showed a slight movement of calcium when the soil had been treated with burned limestone, while the soil from the pots leached for twelve months with similar treatments did not show such a movement. This inconsistency cannot be explained unless there was a mechanical movement of calcium in the soil from certain of the pots that were leached for six months. As hereinbefore stated, the results obtained from the soil leached for the longer period are given preference over the others, and this permits 
the conclusion that neither small nor large applications of burned or ground limestone resulted in a downward movement of calcium.

Calcium incorporated with the soil as burned or ground limestone and placed in the bottom of the pots did not move by diffusion into the upper soil layers.

No movement of ground limestone thru the soil was evident when applied at the rate of 9000 pounds to the acre, irrespective of the fineness to which the rock had been ground. There was no difference in the movement of limestone ground to pass a 200-mesh sieve and that ineld on a 32-mesh sieve.

Precipitated calcium carbonate when applied to the soil in large amounts did not move downward to the untreated adjacent soil.

Oats grown in pots on the soil that had been treated with burned limestone had no effect in bringing about a descent of calcium.

It seems logical to believe that a soil deficient in ealeium will absorb this constituent from the drainage water as it percolates thru the soil. No doubt this occurs, but the amount held by the soil is evidently so small that it cannot be detected by a chemical analysis. Conclusions drawn from small differences of calcium found in soil upon analysis are hardly trustworthy, as it is often difficult to obtain concordant results from the same sample of soil. When small differences are calculated to pounds of calcium in an acre foot of soil, as is often done, the real value of such results is questionable.

\section{CONCLUSION}

The results of this investigation are summarized briefly in the following statement:

The translocation of calcium thru a clayey silt loam soil with a rather large lime requirement is extremely slow, since in these experiments no upward nor downward movement of this element was perceptible twelve months after small, large, or excessive amounts of calcium salts were applied to the soil.

\section{ACKNOWLEDGMENT}

The writer desires to acknowledge his indebtedness to Professor T. Lyttleton Lyon, under whose direction this work was done. 


\section{LITERATURE CITED}

Ames, J. W., And Gaither, E. W. Soil investigations. Ohio Agr. Exp. Sta. Bul. 261:449-512. 1913.

Ames, J. W., And Schollenberger, C. J. Liming and lime requirement of soil. Ohio Agr. Exp. Sta. Bul. 306:279-396. 1916.

Broughton, L. B. How lime is distributed through and lost from soils. Maryland Agr. Exp. Sta. Bul. 166:285-326. 1912.

Hall, A. D., AND Mrller, N. H. J. The effect of plant growth and of manures upon the retention of bases by the soil. Roy. Soc. London. Proc. 77в: 1-32. 1905.

KING, F. H. Investigations in soil management, p. 1-168. (Reference on p. 62-86.) 1904.

McIntire, W. H. Results of thirty years of liming. Pennsylvania State Coll. Rept. 1911-12:64-75. 1913.

Mellor, J. W. Higher mathematics for students of chemistry and physics, p. 1-641. (Reference on p. 524.) 1909.

Shorey, Edmund C., Fry, Willyam H., and Hazen, William. Calcium compounds in soils. Journ. agr. research 8:57-77. 1917.

Surth, Eugene A. Table of analyses of Alabama soils and subsoils. In Report on the cotton production of the State of Alabama. Tenth U. S. Census (1880) $6^{2}: 71-74.1884$.

SNYder, Harry. The chemical composition of soils. In Soil investigations. Minnesota Univ. Agr. Exp. Sta. Bul. 65:1-39. 1899.

Vertch, F. P. Comparison of methods for the estimation of soil acidity. Amer. Chem. Soc. Journ. 26:637-662. (Reference on p. 659.) 1904.

- Summary of experiments on the relation of soil acidity to fertility: In Proceedings of the twenty-first annual convention of the Association of Official Agricultural Chemists. U. S. Bur. Chem. Bul. $90: 183-187.1905$.

White, J. W. The results of long continued use of ammonium sulphate upon a residual limestone soil of the Hagerstown series. Pennsylvania State Coll. Rept. 1912-132:55-104. 1914.

Wrlson, James K. Calcium hypochlorite as a seed sterilizer. Amer. journ. bot. $2: 420-427.1915$.

Wood, T. B., and Stratton, F. J. M. The interpretation of experimental results. Journ. agr. sci. 3:417-440. 1910.

Memoir 15, Insects Injurions to the Hop in New York, the second preceding number in this series of publications, was mailed on November $19,1918$. 


\section{(1) 11}

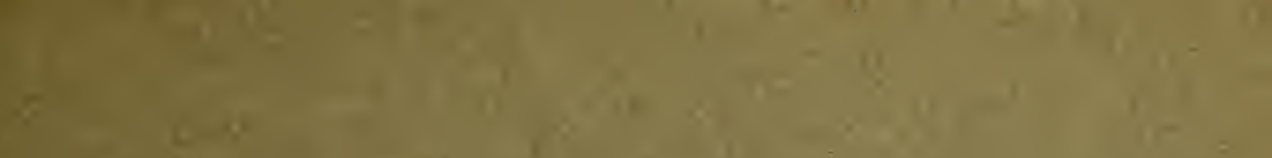

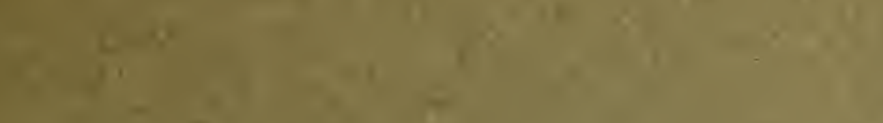

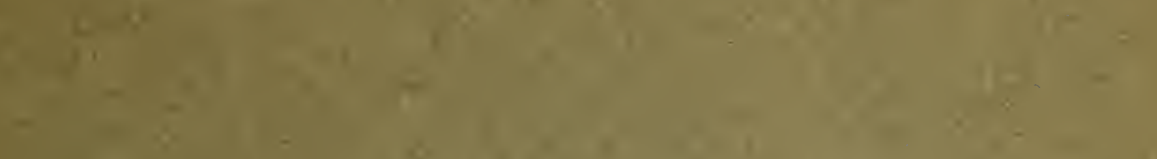

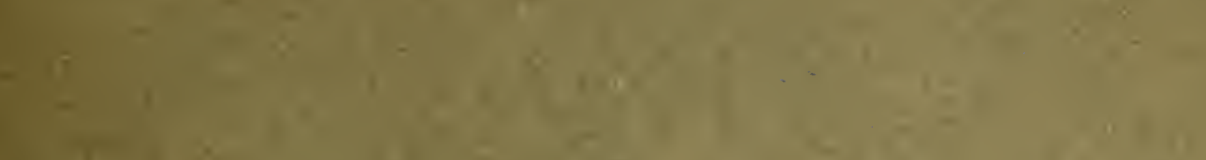

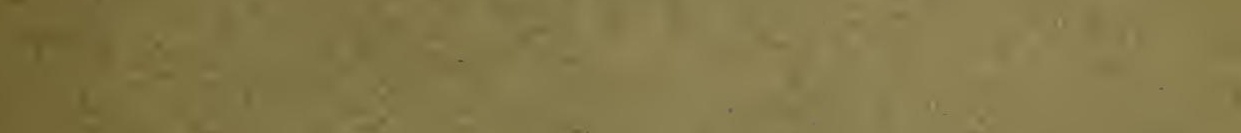

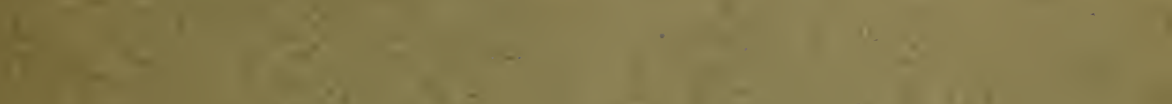

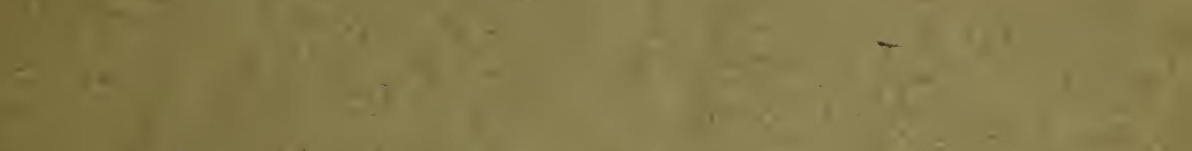

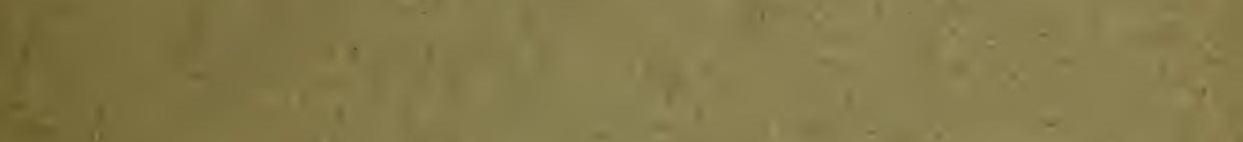

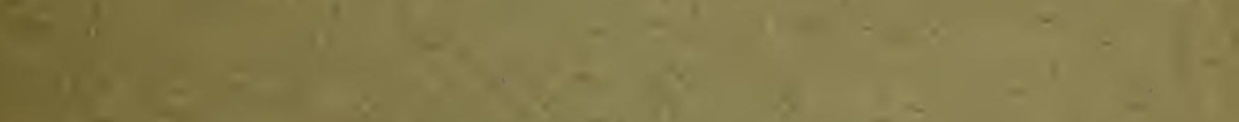

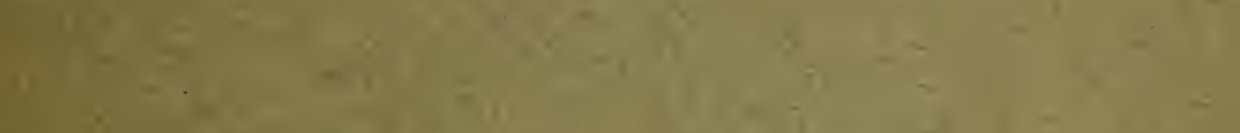

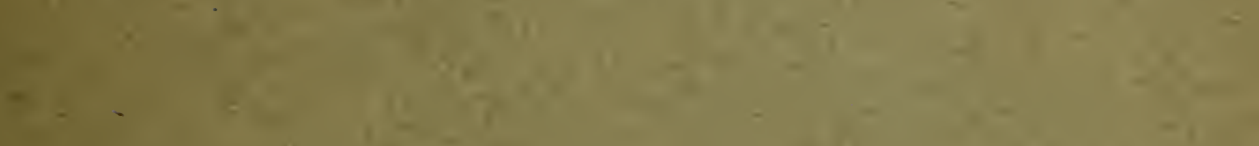

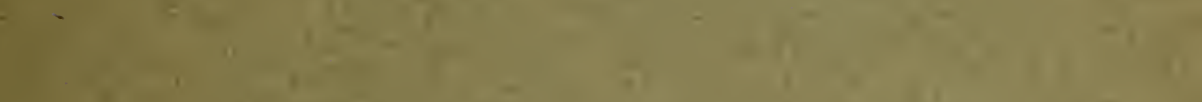

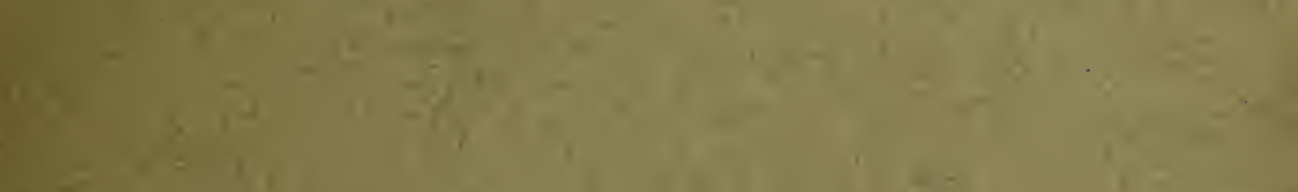

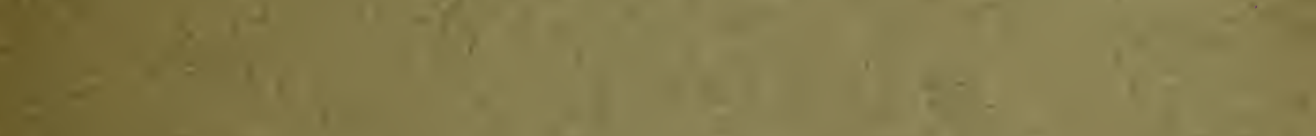

.

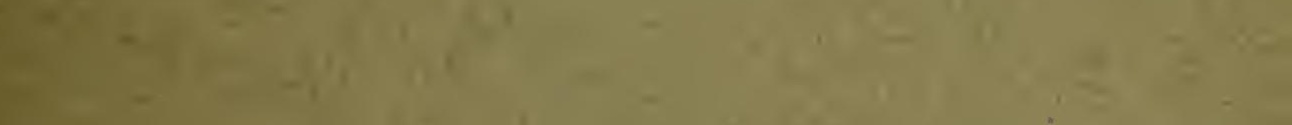

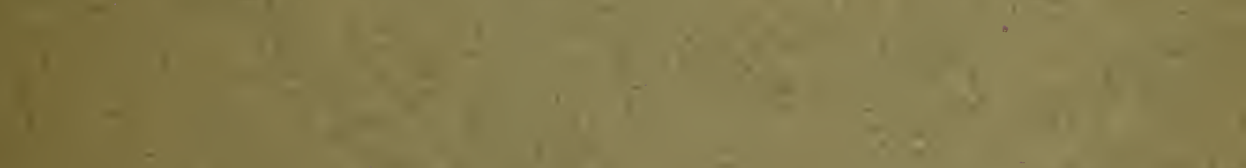
-

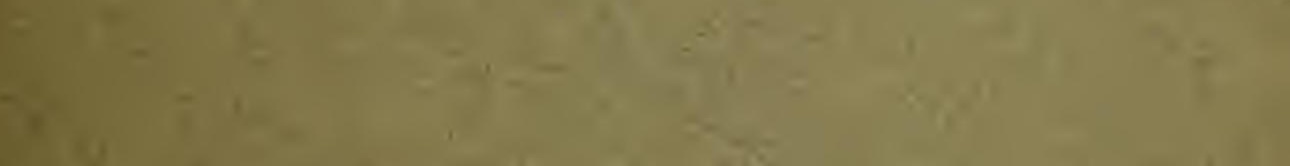

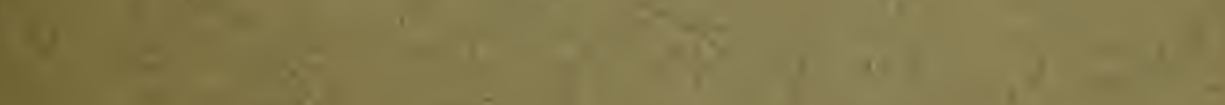

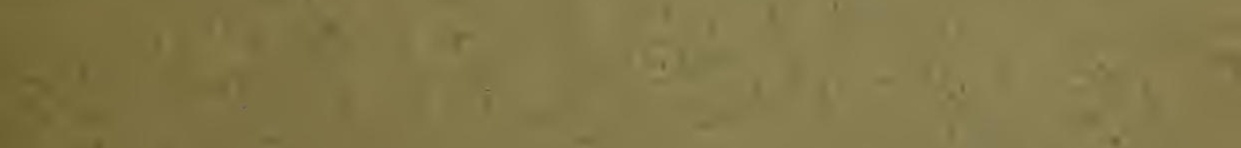
7.

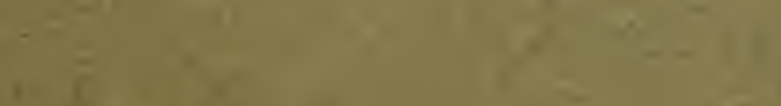


LIBRARY OF CONGRESS

002672739 A 